\title{
Originals
}

\section{The Effect of hGH Deficiency on the Insulin Response to Glucagon after Oral Glucose Loading}

\author{
Z. Laron ${ }^{1}$, M. Mimouni, Z. Josefsberg, Z. Zadik, and M. Doron \\ Institute of Paediatric and Adolescent Endocrinology and Israel Counselling Centre for Juvenile Diabetics, Beilinson Medical Centre \\ and Sackler School of Medicine, Tel Aviv University, Israel
}

\begin{abstract}
Summary. Six children and adolescents (aged from $2^{6} / 12$ to 16 years) with isolated hGH deficiency were subjected to a standard oral glucose tolerance test (OGTT) followed by the administration of IV glucagon at 180 mins. Three of them underwent a second test after several months of hGH therapy. Nine patients underwent a separate IV glucagon test and two of these patients had both tests. As controls served 14 endocrinologically normal children and adolescents, who underwent both tests. It was found that the patients with isolated hGH deficiency had lower basal plasma insulin and blood glucose levels and that their insulin response to IV glucagon even after oral glucose preloading was significantly lower than in the control group. This response was partially restored by several months of hGH treatment in the three patients tested. These findings are interpreted as further evidence for an insulinotrophic effect of hGH.
\end{abstract}

Key words: hGH deficiency, Insulin response to IV glucagon, Insulin response to glucose, Insulin, Children and adolescents, Glucagon, OGTT.

A number of studies carried out in both animals and man have shown that the insulin response to glucagon is augmented by hyperglycaemia [1-4] and blunted by hypoglycaemia [5]. Most of the investigations performed in man were carried out in adults with the glucose administered by constant infusion and the glucagon usually at hyperglycaemic levels. A previous study done by us in a group of children

\footnotetext{
1 Established Investigator of the Chief Scientist's Bureau, Ministry of Health
}

with constitutional growth retardation and no endocrine dysfunction revealed that oral glucose preloading augments the insulin response to I V glucagon, without relation to the concomitant blood glucose concentration [6]. The study presented below was planned to investigate this effect in patients with hGH deficiency.

\section{Subjects and Methods}

Thirteen children and adolescents with isolated hGH deficiency, eight males and five females ranging in age from $26 / 12$ to 16 years as well as 14 control children and adolescents, 12 males and two females aged from $7^{6 / 12}$ to $18^{6 / 12}$ years, form the subject material of this study. All patients were ambulatory.

Six patients underwent a standard oral glucose tolerance test (OGTT) followed by the IV administration of glucagon at $180 \mathrm{~min}$. Three of them underwent a second combined test after several months of hGH therapy ( $2 \mathrm{mg}$ IM three times weekly). Nine patients underwent a separate IV glucagon test; of these two underwent both tests. As controls served 14 children and adolescents with slight short stature (i. e. height on 3rd percentile or slightly below) with no discernible endocrine disorder [6], all of whom underwent both tests.

The OGTT $(1.75 \mathrm{~g} / \mathrm{kg}$ body weight) was performed after an overnight fast and a high carbohydrate diet during the 3 days prior to the test. An indwelling needle was inserted into the antecubital vein and after the subject had rested for an hour blood was drawn at $0,30,60,90,120,150,180$, $182,185,190,200$ and 210 minutes into heparinized tubes. The glucose intake lasted about $3 \mathrm{~min}$. At $180 \mathrm{~min}$ glucagon (Lilly) was administered in one intravenous bolus at a dose of 
Table 1. The mean blood glucose and plasma insulin response to oral glucose $(1.75 \mathrm{~g} / \mathrm{kg})$ followed by I V glucagon $(0.03 \mathrm{mg} / \mathrm{kg})$ injected at $180 \mathrm{~min}$ in 6 children and adolescents with isolated hGH deficiency as compared to 14 controls

\begin{tabular}{|c|c|c|c|c|c|c|c|c|c|c|c|c|c|c|c|}
\hline \multicolumn{16}{|c|}{ Glucose $m g / d l( \pm S E M)$} \\
\hline Diagnosis & $\begin{array}{l}\text { Time } \\
\text { min }\end{array}$ & 0 & 30 & 60 & 90 & 120 & 150 & 180 & Peak & 182 & 185 & 190 & 200 & 210 & Peak \\
\hline Isolated hGH & & 75 & 109 & 107 & 103 & 98 & $\begin{array}{c}89 \\
+135\end{array}$ & 92 & 119 & 137 & 103 & 113 & 110 & 100 & $\begin{array}{r}149 \\
+\quad 25\end{array}$ \\
\hline $\begin{array}{r}\text { Deficiency } \\
(\mathrm{n}=6)\end{array}$ & & \pm 4.3 & \pm 3.8 & \pm 5.0 & \pm 11.6 & \pm 3.9 & \pm 13.5 & \pm 0.5 & \pm 5.4 & \pm 25.2 & \pm 8.4 & \pm 8.0 & \pm 12.3 & \pm 13.6 & \pm 25 \\
\hline $\begin{array}{l}\text { Controls } \\
(\mathrm{n}=14)\end{array}$ & & $\begin{array}{l}85 \\
\pm 2.7\end{array}$ & $\begin{array}{l}117 \\
\pm 4.4\end{array}$ & $\begin{array}{l}113 \\
\pm 7.0\end{array}$ & $\begin{array}{l}108 \\
\pm 7.6\end{array}$ & $\begin{array}{l}103 \\
\pm 4.1\end{array}$ & $\begin{array}{r}85 \\
\pm 4\end{array}$ & $\begin{array}{l}87 \\
\pm 2.9\end{array}$ & $\begin{array}{l}125 \\
\pm 5.1\end{array}$ & $\begin{array}{l}109 \\
\pm 6.2\end{array}$ & $\begin{array}{l}114 \\
\pm 7.6\end{array}$ & $\begin{array}{l}110 \\
\pm 7.2\end{array}$ & $\begin{array}{l}104 \\
\pm 6.6\end{array}$ & $\begin{array}{l}91 \\
\pm 6.7\end{array}$ & $\begin{array}{l}121 \\
\pm 7.8\end{array}$ \\
\hline $\begin{array}{l}\text { Statistical } \\
\text { Evaluation }\end{array}$ & & $\begin{array}{l}\mathrm{S}^{2}=0 . \\
\mathrm{p}<0 . \mathrm{C}\end{array}$ & & NS & NS & NS & NS & NS & $\begin{array}{l}S^{2}=0.8 \\
p<0.1\end{array}$ & NS & NS & NS & NS & NS & NS \\
\hline \multicolumn{16}{|c|}{ Insulin $\mu U / m l( \pm S E M)$} \\
\hline Diagnosis & $\begin{array}{l}\text { Time } \\
\text { min }\end{array}$ & 0 & 30 & 60 & 90 & 120 & 150 & 180 & Peak & 182 & 185 & 190 & 200 & 210 & Peak \\
\hline $\begin{array}{l}\text { Isolated hGH } \\
\text { deficiency } \\
\quad(n=6)\end{array}$ & & $\begin{array}{r}7.4 \\
\pm 0.7\end{array}$ & $\begin{array}{r}13.7 \\
\pm 2.4\end{array}$ & $\begin{array}{l}15 \\
\pm 3.3\end{array}$ & $\begin{array}{r}15.7 \\
\pm 3.7\end{array}$ & $\begin{array}{r}13.5 \\
\pm 2.7\end{array}$ & $\begin{array}{r}16.5 \\
\pm 0.3\end{array}$ & $\begin{array}{r}15.5 \\
\pm 0.9\end{array}$ & $\begin{array}{r}20.0 \\
\pm 2.8\end{array}$ & $\begin{array}{r}58.2 \\
\pm 11.2\end{array}$ & $\begin{array}{r}33.7 \\
\pm 11.0\end{array}$ & $\begin{array}{r}21.7 \\
\pm 2.1\end{array}$ & $\begin{array}{r}12.8 \\
\pm 3.1\end{array}$ & $\begin{array}{r}12.9 \\
\pm 4.2\end{array}$ & $\begin{array}{r}58.2 \\
\pm 11.2\end{array}$ \\
\hline $\begin{array}{l}\text { Controls } \\
(n=14)\end{array}$ & & $\begin{array}{r}11.7 \\
\pm 1.9\end{array}$ & $\begin{array}{r}39.6 \\
\pm 6.4\end{array}$ & $\begin{array}{r}38.8 \\
\pm 6.2\end{array}$ & $\begin{array}{r}40.3 \\
\pm 6.2\end{array}$ & $\begin{array}{r}46.7 \\
\pm 6.2\end{array}$ & $\begin{array}{l}31.4 \\
\pm 6\end{array}$ & $\begin{array}{l}24.5 \\
\pm 5\end{array}$ & $\begin{array}{r}58.1 \\
\pm 6.6\end{array}$ & $\begin{array}{r}231.6 \\
\pm 49.3\end{array}$ & $\begin{array}{r}203.6 \\
\pm 39.3\end{array}$ & $\begin{array}{l}142 \\
\pm 25.1\end{array}$ & $\begin{array}{r}55.6 \\
\pm 10.5\end{array}$ & $\begin{array}{r}38.5 \\
\pm 5.9\end{array}$ & $\begin{array}{r}253.4 \\
\pm 47.9\end{array}$ \\
\hline $\begin{array}{l}\text { Statistical } \\
\text { Evaluation }\end{array}$ & $\begin{array}{l}S^{2} \\
\mathrm{p}\end{array}$ & NS & $\begin{array}{c}0.4 \\
<0.02\end{array}$ & $\begin{array}{c}0.5 \\
<0.02\end{array}$ & $\begin{array}{c}0.7 \\
<0.05\end{array}$ & $\begin{array}{r}0.4 \\
<0.0\end{array}$ & $\begin{array}{l}\text { NS } \\
05\end{array}$ & NS & $\begin{array}{c}0.3 \\
<0.01\end{array}$ & $\begin{array}{l}1.9 \\
<0.02\end{array}$ & $\begin{array}{c}3.7 \\
<0.1\end{array}$ & $\begin{array}{l}0.3 \\
<0.01\end{array}$ & $\begin{array}{l}0.6 \\
<0.02\end{array}$ & $\begin{array}{r}1.4 \\
2<0.1\end{array}$ & $\begin{array}{c}1.9 \\
<0.02\end{array}$ \\
\hline
\end{tabular}

$\mathrm{S}^{2}=$ Analysis of variance; $\mathrm{p}=$ According to Student's $\mathrm{t}$ test

Table 2. The mean blood glucose and plasma insuljn response to a single I V glucagon $(0.03 \mathrm{mg} / \mathrm{kg})$ in 9 children and adolescents with hGH deficiency as compared to 14 controls

\begin{tabular}{|c|c|c|c|c|c|c|c|c|}
\hline \multicolumn{9}{|c|}{ Glucose $m g / d l( \pm S E M)$} \\
\hline Diagnosis & $\begin{array}{l}\text { Time } \\
\text { min }\end{array}$ & 0 & 2 & 5 & 10 & 20 & 30 & Peak \\
\hline $\begin{array}{l}\text { Isolated hGH } \\
\text { deficiency }(\mathrm{n}=9)\end{array}$ & & $\begin{array}{l}83 \\
\pm 1.8\end{array}$ & $\begin{array}{l}90 \\
\pm 7.4\end{array}$ & $\begin{array}{l}91 \\
\pm 5.5\end{array}$ & $\begin{array}{l}101 \\
\pm 5.6\end{array}$ & $\begin{array}{l}118 \\
\pm 7.5\end{array}$ & $\begin{array}{l}116 \\
\pm 7.5\end{array}$ & $\begin{array}{l}118 \\
\pm 7.1\end{array}$ \\
\hline $\begin{array}{l}\text { Controls } \\
(\mathrm{n}=14)\end{array}$ & & $\begin{array}{l}87 \\
\pm 2.1\end{array}$ & $\begin{array}{l}85 \\
\pm 2.2\end{array}$ & $\begin{array}{l}97 \\
\pm 2.0\end{array}$ & $\begin{array}{l}108 \\
\pm 2.8\end{array}$ & $\begin{array}{l}124 \\
\pm 3.2\end{array}$ & $\begin{array}{l}137 \\
\pm 5.0\end{array}$ & $\begin{array}{l}137 \\
\pm 4.9\end{array}$ \\
\hline $\begin{array}{l}\text { Statistical } S^{2} \\
\text { Evaluation } \mathrm{p}\end{array}$ & & $\begin{array}{r}0.2 \\
<0.1\end{array}$ & NS & NS & NS & NS & $\begin{array}{c}0.1 \\
<0.01\end{array}$ & $\begin{array}{l}0.1 \\
<0.01\end{array}$ \\
\hline \multicolumn{9}{|c|}{ Insulin $\mu U / m l( \pm S E M)$} \\
\hline Diagnosis & $\begin{array}{l}\text { Time } \\
\text { min }\end{array}$ & 0 & 2 & 5 & 10 & 20 & 30 & Peak \\
\hline $\begin{array}{l}\text { Isolated hGH } \\
\text { deficiency }(\mathrm{n}=9)\end{array}$ & & $\begin{array}{r}10.9 \\
\pm 0.7\end{array}$ & $\begin{array}{l}63.4 \\
\pm 11.1\end{array}$ & $\begin{array}{r}34.5 \\
\pm 9.3\end{array}$ & $\begin{array}{r}25.6 \\
\pm 6.4\end{array}$ & $\begin{array}{r}23.7 \\
\pm 5.5\end{array}$ & $\begin{array}{r}18.1 \\
\pm 3.8\end{array}$ & $\begin{array}{r}69.4 \\
\pm 11.6\end{array}$ \\
\hline $\begin{array}{l}\text { Controls } \\
(n=14)\end{array}$ & & $\begin{array}{r}8.9 \\
\pm 1.3\end{array}$ & $\begin{array}{l}72.1 \\
\pm 13.5\end{array}$ & $\begin{array}{r}59.3 \\
+11.8\end{array}$ & $\begin{array}{r}37.3 \\
\pm 6.8\end{array}$ & $\begin{array}{r}31.1 \\
\pm 6.7\end{array}$ & $\begin{array}{r}30.1 \\
\pm 5.0\end{array}$ & $\begin{array}{r}79.2 \\
\pm 13.8\end{array}$ \\
\hline $\begin{array}{l}\text { Statistical } \mathrm{S}^{2} \\
\text { Evaluation } \mathrm{p}\end{array}$ & & NS & NS & NS & NS & NS & NS & NS \\
\hline
\end{tabular}

$\mathrm{S}^{2}=$ Analysis of variance; $\mathrm{p}=$ According to Student's $\mathrm{t}$ test

$0.03 \mathrm{mg} / \mathrm{kg}$ body weight. Blood for glucose was separated, the tubes centrifuged and the plasma frozen at $-20^{\circ} \mathrm{C}$ until assayed. The single intravenous glucagon test was performed without any special dietary preparation and blood was drawn at $0,2,5$, 10,20 and $30 \mathrm{~min}$.

Blood glucose was measured with a Technicon Autoanalyzer by ferricyanide colorimetry. Plasma insulin was assayed using a double-antibody radioimmunoassay [7]. Statistical evaluation was performed using Student's $t$ test, and by analysis of variance.

\section{Results}

Table 1 shows the effect upon blood glucose and plasma insulin of oral glucose followed by I V glucagon at $180 \mathrm{~min}$ as compared with that obtained in 
Table 3. Plasma insulin response to oral glucose and I V glucagon injected at $180 \mathrm{~min}$ in 3 children with isolated hGH deficiency, before and during $\mathrm{hGH}$ treatment

\begin{tabular}{|c|c|c|c|c|c|c|c|}
\hline \multicolumn{8}{|c|}{ Plasma Insulin $\mu U / m l$} \\
\hline \multirow[t]{2}{*}{ Test } & \multirow{2}{*}{$\begin{array}{l}\text { Treatment } \\
\text { Minutes }\end{array}$} & \multicolumn{2}{|c|}{ Patient 1} & \multicolumn{2}{|c|}{ Patient 2} & \multicolumn{2}{|c|}{ Patient 3} \\
\hline & & None & hGH & None & hGH & None & hGH \\
\hline \multirow[t]{7}{*}{ OGTT } & 0 & 6.5 & 2 & 6.6 & 5.4 & 8.9 & 9.1 \\
\hline & 30 & 7 & 11.7 & 13. & 9.7 & 13.3 & 25.7 \\
\hline & 60 & 11 & 8.6 & 13.9 & 31.0 & 23.5 & 34.5 \\
\hline & 90 & 11 & 16.8 & 30.1 & 20.9 & - & 55.3 \\
\hline & 120 & 10 & 19.8 & 17.9 & 10.4 & 23.7 & 32 \\
\hline & 150 & & 8.0 & - & 26.7 & - & 42.5 \\
\hline & 180 & & 10.0 & - & 9 & - & 19.6 \\
\hline IV & 182 & 61 & 88.1 & 49.8 & 111.8 & 21.7 & 168.9 \\
\hline \multirow[t]{4}{*}{ Glucagon } & 185 & 54.5 & 111.3 & - & 109.2 & 29.9 & 111.7 \\
\hline & 190 & 28 & 33.4 & 18.9 & 93.8 & 27.3 & 126.7 \\
\hline & 200 & 10 & 13.1 & 15.3 & 72.2 & 16.9 & 61.7 \\
\hline & 210 & 8.5 & 14.8 & - & 31.1 & - & 45.1 \\
\hline
\end{tabular}

Peak values are in italics

the separate intravenous glucagon test (Table 2). As the response in all the patients with $\mathrm{hGH}$ deficiency and controls was similar, the mean of each group has been given. In addition to the actual mean values for a certain time, the mean values of the individual peak response without consideration of the time when it occurred, are also given.

\section{Glucose Response}

During the combined test the mean basal levels of the hGH deficient patients was lower than that of the controls, so was the mean peak after the glucose load. The peak levels during the I V glucagon test were similar. In the separate I V glucagon test in both groups the rise of glucose was slower than that seen when it was performed following the OGTT. The mean peak response value was significantly higher in the control group than in the hGH deficient children in whom the mean value was similar to that when the I V glucagon was preceded by an OGTT.

\section{Insulin Response}

In the patients lacking hGH the mean basal level of insulin was throughout significantly lower than in the controls, as was the mean response of insulin to the glucose load and that following I V glucagon.

In the control children the preloading of oral glucose markedly enhanced the insulin response to I $\mathrm{V}$ glucagon in comparison to that obtained with the separate administration of I V glucagon, whereas in the patients lacking hGH, the response was very similar (the small difference between the two mean peak responses was not significant).

\section{Effect of hGH Treatment}

Table 3 shows the insulin response in the two tests carried out in three children with isolated hGH deficiency who had received hGH therapy for 6 months or more. It is evident that after hGH therapy the insulin response after I V glucagon was markedly enhanced in all three; in two the response to OGTT was slightly enhanced. The basal insulin values remained unchanged.

\section{Discussion}

In patients lacking pituitary hGH secretion, blood glucose levels tend to be low and basal plasma insulin concentrations are low despite obesity [8], and the plasma insulin response to arginine [9] or glucose $[10,11,12]$ is often reduced. These findings can be explained if one assumes that pituitary growth hormone plays a physiologic role in the capacity of the pancreas to secrete insulin $[13,14]$.

The present study provides further evidence for the insulinotrophic property of human growth hormone. Measuring the plasma insulin concentrations during an oral glucose load followed by intravenous injection of glucagon in endocrinologically normal children and those with hGH deficiency, we observed that the latter had lower basal plasma insulin levels than the former and that the insulin response to I V glucagon was reduced. Preloading with oral glucose led to an enhancement of the insulin response to I V glucagon in normal children and adolescents [6], but had only a limited effect in the patients with isolated hGH deficiency.

It is of note that treatment with hGH in three of these children restored the capacity of insulin secre- 
tion in response to I V glucagon after glucose preloading. To the best of our knowledge, this observation has not been reported previously.

The insulinotrophic effect of hGH demonstrated in this investigation can be explained by a direct action of the hGH on the readily-available insulin pool, which is responsive to glucagon stimulation and takes place even when there are no significant differences in the peak blood glucose concentrations. That a prolonged lack of hGH markedly impairs liver glycogen storage is indicated by the lower basal concentration of blood glucose and the faster decrease after peaking in the combined test, and the lower peak in the separate I V glucagon test in the children with hGH deficiency. Differences in circulating concentrations of substrates such as amino acids and fatty acids or in epinephrine may also influence the responsiveness of the enteroinsular mechanism.

hGH may also play a permissive role in the normal functioning of the beta-cell membrane receptors, the intracellular formation of insulin and/or its release by glucagon and glucose. As already suggested [6], glucagon may have a direct effect on the beta-cell, possibly through receptors separate from that of glucose, the activation of which causes immediate insulin release from a pool, part of which may be predetermined by glucose stimulation.

Treatment with hGH restored the capacity of the beta cell of the hGH deficient patients to respond to glucagon. Similar findings were reported by Underwood et al. [15] who studied the insulin response to I V glucagon, glucose, leucine and epinephrine in four children with multiple pituitary hormone deficiencies. In their patients, two of whom were definitely also ACTH deficient, cortisol administration augmented the insulin response during hGH therapy.

It is of note that despite a low insulin response, the growth hormone deficient children are not diabetic. This might well indicate an increased sensitivity of peripheral tissue to insulin. We have made similar observations in a group of constitutionally short and lean children with normal secretion of hGH $[16,17]$; thus the increased peripheral sensitivity to insulin which may account for the lower fasting blood glucose concentrations in the hypopituitary children, may have other contributing factors than hGH lack.

\section{References}

1. Garcia, M.J., Czerwinski, C., DeSantis, R., Lan, V.V., Ramoy, E., Penhos, J.C.: Hyperglycemia and insulinogenic effects of intravenous glucagon at different blood glucose levels. Proc. Soc. Exp. Biol. Med. 143, 707-710 (1973)

2. Ryan, W.G., Nibbe, A.E.: Beta-cytotrophic effects of glucose, glucagon and tolbutamide in man. Lancet $1967 \mathrm{I}$, $1255-1256$

3. Ryan, W. G., Schwartz, T.B., Nibbe, A.E:: Serum immunoreactive insulin levels during glucose tolerance and intensive islet stimulation. Diabetes 20, 404-409 (1971)

4. Cerasi, E.: Mechanism of glucose stimulated insulin secretion in health and in diabetes: Some re-evaluations and proposals. Diabetologia 11, 1-13 (1975)

5. Goldfine, I. D., Cerasi, E., Luft, R.: Glucagon stimulation of insulin release in man: inhibition during hypoglycemia. J. Clin. Endocrinol. Metab. 35, 312-315 (1972)

6. Josefsberg, Z., Flatau, E., Doron, M., Laron, Z.: The influence of oral glucose loading on the insulin response to IV glucagon in children and adolescents. Metabolism 25, 277-280 (1976)

7. Hales, C.N., Randle, R. J.: Immunoassay of insulin with insulin-antibody precipitate. Biochem. J. 88, 137-146 (1963)

8. Laron, Z.: The hypothalamus and the pituitary gland (Hypophysis). In: D.W. Hubble (Ed.): Paediatric Endocrinology, pp. 35-111. Oxford: Blackwell Sci. Publ. 1969

9. Laron, Z.: Activity of endogenous growth hormone. Lancet 1967 II, 1094-1095

10. Merimee, T. J., Burgess, J. A., Rabinowitz, D.: Influence of growth hormone on insulin secretion. Studies of growth hormone deficient subjects. Diabetes 16, 478-482 (1967)

11. Laron, Z., Pertzelan, A., Karp, M.: Glucose intolerance in children and young adults with dwarfism due to hGH deficiency and with the syndrome of dwarfism and high plasma IR-hGH. In: Z. Laron, M. Karp (Eds.): Diabetes in Juveniles - Modern Problems in Paediatrics. Vol. 12, pp. 109-117. Basel: S. Karger 1975

12. Costin, G., Kogut, M.D., Frasier, S.D.: Effect of low-dose human growth hormone on carbohydrate metabolism in children with hypopituitarism. J. Pediatr. 80, 796-803 (1972)

13. Martin, J. M., Gagliardino, J. J.: Effect of growth hormone on the isolated pancreatic islets of the rat in vitro. Nature 213, 630-631 (1967)

14. Rabinowitz, D., Merimee, J. J.: Isolated human growth hormone deficiency and related disorders. Isr. J. Med. Sci. 9, 1599-1657 (1973)

15. Underwood, L.E., Van den Brande, J.L., Antony, G. J., Voina, S.J., Van Wyk, J.J.: Islet function and glucose homeostasis in hypopituitary dwarfism: Synergism between growth hormone and cortisone. J. Pediatr. 82, 28-37, (1973)

16. Laron, Z., Karp, M., Pertzelan, A., Kauli, R.: Insulin, growth and growth hormone. Isr. J. Med. Sci. 8, 440-452 (1972)

17. Karp, M., Laron, Z., Doron, M.: Insulin secretion in children with constitutional familial short stature. J. Pediatr. 83, 241-246 (1973)

Received: December 22, 1976, and in revised form: March 30, 1977

Prof. Z. Laron

Institute of Paediatric

and Adolescent Endocrinology

Beilinson Medical Centre

Petah Tikva

Israel 